\title{
AS SENTENÇAS INTERPRETATIVAS E O ATIVISMO JUDICIAL: Os Limites Hermenêuticos Necessários à Manutenção da Legitimidade do Estado Democrático de Direito
}

http://dx.doi.org/10.21527/2176-6622.2020.54.260-272

Recebido em: 26/8/2020

Aceito em: 1의 $9 / 2020$

Alfredo Copetti Neto

Pós-Doutorado na Universidade do Vale do Rio dos Sinos (Unisinos/PDJ-CNPq, 2014). Doutorado em Teoria do Direito e da Democracia pela Università degli Studi Roma Tre (Uniromatre, 2010 - Revalidado UFPR). Mestrado em Direito Público (Filosofia do Direito) pela Universidade do Vale do Rio dos Sinos (Unisinos, 2006). Editor da Revista do Instituto de Hermenêutica Jurídica (1678-1864). Coordenador do Grupo Nedei (Direito Economia e Instituições UniFG), do Grupo Direito e Regulações (Univel) e membro pesquisador do grupo Estado e Constituição do Cnpq. Professor visitante na Universitá di Roma (La Sapienza). Professor-adjunto de Teoria do Direito da Universidade Estadual do Paraná (Unioeste). Professor do PPG-G UniFG e da Univel. Consultor Ad Hoc Capes. É membro fundador do "Centro di Studi di Diritto dell “Economia Brasile-Italia”. Membro da Rede Brasil-Itália-Espanha de Direito Público. Membro do Comitê Brasileiro de Compliance. Tem experiência na área de Direito, com ênfase em Teoria do Direito, Garantismo Jurídico e Direito Econômico. Atua, principalmente, nos seguintes temas: Garantias Constitucionais, Direitos Fundamentais, Democracia Substancial e Direito Econômico com ênfase na Análise Econômica do Direito (Law and Economics). http://lattes.cnpq.br/6336504347602827. http://orcid.org/0000-0002-6997-9603. alfredocopetti@yahoo.com

\section{Lucas Gabriel Ladeia Cirne}

Mestrando em Direito pelo Programa de Pós-Graduação Stricto Sensu do Centro Universitário Guanambi (UniFG). Especialista em Direito Processual Civil pela Faculdade de Direito Professor Damásio de Jesus. Graduado em Direito pelo Centro Universitário Jorge Amado (Unijorge). Membro do Núcleo de Estudos de Direito, Economia e Instituições (Nedei). Advogado, inscrito na OAB/BA no 32.761. http://lattes.cnpq.br/4161407213416594. http://orcid.org/0000-0002-9354-7405. lucasladeia@yahoo.com.br

\section{RESUMO}

O presente artigo objetiva discutir a importância das sentenças interpretativas - interpretação conforme e nulidade sem redução do texto - na jurisdição constitucional, salientando, todavia, que a sua utilização deve necessariamente respeitar determinados limites hermenêuticos e o texto da Constituição. Nesse sentido, a ideia é destacar a linha tênue que separa a legitimidade da aplicação dos mecanismos interpretativos em questão do ativismo judicial, surgido a partir de equívocos em sua aplicação. Para tanto, busca-se, inicialmente, discorrer sobre os aludidos temas, reforçando o caráter hermenêutico dos instrumentos de interpretação citados, analisando as suas especificidades, hipóteses e limites para, em um segundo momento, avaliar as relações havidas entre essas ferramentas e o ativismo judicial. Por fim, com a apresentação de um julgado exemplificador da simbiose entre os dois temas, pretende-se confirmar o valor dos modelos interpretativos em tela, bem como a obrigação de eles serem aplicados dentro de um quadro rígido, vinculante e limitador, a fim de se manter o equilíbrio da democracia dentro do Estado de Direito.

Palavras-chave: Ativismo judicial. Hermenêutica constitucional. Sentenças interpretativas.

INTERPRETATIVE SENTENCES AND JUDICIAL ACTIVISM: THE HERMENEUTIC LIMITS NEEDED TO MAINTAIN THE LEGITIMACY OF THE DEMOCRATIC STATE OF LAW

\section{ABSTRACT}

This article aims to discuss the importance of interpretative sentences - consistent interpretation and nullity without text reduction - in constitutional jurisdiction, stressing, however, that their use must necessarily regard certain hermeneutic limits and the text of the Constitution. In this sense, the idea is to highlight the fine line between the legitimacy of the application from the interpretive mechanisms in question, from the judicial activism, which arised from being mistakenly applied. To this end, it seeks, initially, to discuss the aforementioned themes, reinforcing the hermeneutic character of the previously referred instruments of interpretation, analyzing their specificities, hypotheses and limits to, in a later moment, assess the relationships between these tools and judicial activism. Ultimately, with the introduction of an exemplary judgment of the symbiosis between the two themes, it is intended to confirm the value of the interpretive models in discussion, as well as their obligation to be applied within a rigid, binding and limiting framework, in order to maintain the balance of democracy within the State of the Law.

Keywords: Judicial activism. Constitutional hermeneutic. Interpretative sentences.

\section{SUMÁRIO}

1 Introdução. 20 contexto histórico do surgimento da contemporânea jurisdição constitucional. 3 As sentenças interpretativas dentro do contexto da jurisdição constitucional contemporânea. 4 Os limites hermenêuticos e o desvirtuamento das sentenças interpretativas. 5 Judicialização, ativismo judicial, discricionariedade e interpretação constitucional. 6 A ADI 6.012/MS: a linha tênue entre as sentenças interpretativas e o ativismo judicial. 7 Conclusão. 7 Referências. 


\section{INTRODUÇÃO}

O exercício da jurisdição constitucional, baseado na análise da compatibilidade de normas infraconstitucionais com o texto da Lei Maior, foi alçado a um patamar ainda mais significativo a partir da promulgação da Carta de 1988. Destarte, embora presente na legislação pátria desde o século 19, o controle de constitucionalidade foi reforçado ante o surgimento do modelo de Estado Constitucional e da consequente criação da Constituição rígida, vista como norte supremo do ordenamento jurídico brasileiro.

Nesse contexto, a prática do Supremo Tribunal Federal foi pautada, doravante, na análise de normas legais e consequente declaração de constitucionalidade ou inconstitucionalidade de um ato normativo. Ocorre que, a partir da valorização da Constituição como fonte primária do ordenamento jurídico, passou-se a observar também a materialidade da norma - e não apenas o seu aspecto formal - para fins de adequação da legislação infraconstitucional ao paradigma constitucional e ao seu texto. Desse modo, com base na concepção de que um texto é válido "se estiver em conformidade com a Constituição, tem-se no texto constitucional, entendido em sua materialidade, o horizonte do sentido que servirá para essa conformação hermenêutica" (STRECK, 2018, p. 386). Ora, sendo a Carta Magna o ápice normativo do qual emanam os pressupostos da construção do Estado Democrático de Direito, os textos infraconstitucionais precisam, obrigatoriamente, serem revestidos por seu manto (STRECK, 2018).

Em paralelo a esse processo de reforço do caráter material da Constituição, a hermenêutica jurídica passa por uma transformação ocorrida, em especial, no século 20 , proporcionado pela viragem linguístic, ${ }^{1} \mathrm{o}$ que, além de materializar o citado salto paradigmático (STRECK, 2018), rebusteceu a necessidade de se utilizar novas técnicas de interpretação.

É nesse contexto que os Tribunais brasileiros - notadamente o Supremo Tribunal Federal, órgão responsável pelo controle de constitucionalidade concentrado - começou a vislumbrar possibilidades interpretativas hodiernas, especialmente quando o exercício analítico possuía por objeto normas polissêmicas. Desse modo, o caminho até a decisão acerca da compatibilidade da norma com a Constituição passou a ser permeado por mecanismos de interpretação diversos, a exemplo da interpretação conforme a Constituição e da declaração de nulidade sem redução do texto. Tal concepção ganhou tamanho destaque que foi normatizada em 1999 com a publicação da Lei no 9.868, tendo sido objeto da doutrina nas duas últimas décadas. ${ }^{2}$

Todo esse cenário serviu para reforçar a força do Poder Judiciário e, em especial, da Suprema Corte, que detém, na atualidade, a última palavra sobre a manutenção de qualquer norma no ordenamento jurídico nacional. Esse poder, entretanto, não pode ser exercido de maneira desarrazoada, discricionária e ilimitada, sob pena de caracterização do nocivo ativismo judicial.

Verifica-se, todavia, que a prática da jurisdição constitucional, por vezes, reflete justamente esse contexto de inobservância dos limites hermenêuticos e legais, usando-se, para tanto, inclusive, dos mecanismos interpretativos disponíveis à sua atuação. O que se observa, de maneira mais específica, é a utilização dessas técnicas interpretativas - legítimas, frise-se - de forma equivocada, ou, pior, como fundamento justificador de decisões que violam as balizas constitucionais. Em outras palavras, seja pela atécnia, consagrada a partir do momento em que se aplicam esses mecanismos nas hipóteses em que não são cabíveis, seja pela inobservância das competências e limites estabelecidos pela Constituição no momento da aplicação das sentenças inter-

\footnotetext{
A esse respeito, Lenio Streck afirma que a viragem linguística foi responsável pela superação do modelo interpretativo sujeito-objeto pela relação sujeito-sujeito, o que implicou um redimensionamento da relação do homem com a sociedade, e, por consequência, com os textos. Na mesma direção, segue o autor, a invasão da filosofia pela linguagem provocou no campo jurídico uma revolução hermenêutica que vitimou, em primeiro lugar, as concepções objetivistas e objetificantes acerca do modo de interpretar da dogmática jurídica, conforme pode ser extraído da obra "Jurisdição Constitucional" (2018).

2 Como exemplo da manifestação doutrinária acerca do tema, pode-se citar a obra "A Constituição reinventada pela jurisdição consitucional", de José Adércio Leite Sampaio, de 2002.
} 
pretativas, o ativismo judicial ${ }^{3}$ se faz presente na decisão. Deve-se destacar, nesse contexto, que o equívoco do julgador na utilização de uma técnica ao invés de outra (ou ao invés de nenhuma), pode até ser justificado pela falta de conhecimento acerca das hipóteses de aplicação de cada um dos instrumentos citados, todavia o emprego de uma técnica interpretativa em um caso concreto, apenas para fundamentar uma decisão que ignora os parâmetros legais e constitucionais, é inadmissível no atual paradigma, embora seja recorrente na prática. Vê-se, pois, que não merece prosperar qualquer deliberação que atente contra a técnica formal ou que viole os limites hermenêuticos e constitucionais, sob pena de proliferação da danosa postura ativista.

Desse modo, as posturas ativistas e os métodos interpretativos dialogam no contexto do controle de constitucionalidade em um processo que não somente deslegitima a decisão, mas também desequilibra a relação entre os Poderes no Estado Democrático de Direito.

É essa a questão central que o presente artigo, a partir do método de pesquisa de revisão bibliográfica, busca discutir. Ou seja, o debate centra-se na análise das relações havidas entre os dois institutos referidos. Para tanto, faz-se mister, inicialmente, compreender os conceitos que permeiam as duas técnicas de interpretação destacadas (interpretação conforme e declaração de nulidade sem redução de texto), até mesmo para especificar as hipóteses em que cada uma delas pode ser aplicada, bem como estabelecer uma definição clara do que seja ativismo judicial. Por fim, por meio da apresentação de um julgado proferido pelo Supremo Tribunal Federal, visa-se demonstrar o ponto de interseção existente entre os dois temas, seja no que se refere à reiteração do ativismo judicial a partir da utilização errônea das técnicas interpretativas, seja em relação à aplicação dos citados métodos como instrumento de uma postura discricionária e ativista.

\section{O CONTEXTO HISTÓRICO DO SURGIMENTO DA CONTEMPORÂNEA JURISDIÇÃO CONSTITUCIONAL}

Durante a história, o exercício do poder jurisdicional gravitou entre contextos que ora reforçavam o distanciamento do Estado em favor da liberdade individual, ora vislumbravam o protagonismo do poder estatal, provedor das demandas da sociedade (MEYER, 2017).

No modelo absolutista, por exemplo, o Judiciário apresentava-se como um órgão ligado ao Poder Executivo, o que, em termos finais, significava a submissão aos desejos do monarca (ABBOUD, 2019). Com as revoluções e o surgimento do Estado Liberal, defensor das individualidades, o Poder Judiciário afastou-se e a atividade judicial passou a ser exercida de maneira mecânica, tendo por base a igualdade formal (MEYER, 2017). O posterior advento das transformações sociais, que aumentaram a desigualdade em decorrência da acumulação de capital no ambiente do paradigma liberal (MEYER, 2017), influenciou na ruptura do modelo anterior e no nascimento do Estado Social.

Com efeito, o século 20 foi testemunha de um significativo rompimento paradigmático no campo do direito após o fim da Segunda Guerra Mundial. Igualmente, instituiu-se o hodierno modelo de ciência jurídica, definindo-se novas funções para a legislação (ABBOUD, 2019) e redimensionando-se a posição do Poder Judiciário. Destarte, diante dos horrores gerados pelo conflito, a sociedade decidiu apostar no Poder Judiciário como instituição capaz de fazer valer os ditames do Estado de Direito, conferindo-lhe grande poder interpretativo e decisório a partir do caráter paternal que estabelecia os valores principais (MEYER, 2017).

\footnotetext{
É oportuno salientar que o conceito atual do termo ativismo judicial deriva da doutrina processual alemã e da disciplina política norte-americana, conforme destaca Diego Bacha e Silva (2013). No país europeu a expressão surge com o fim de designar a faculdade conferida ao magistrado de conduzir a colheita de provas através de um modelo inquisitório. Por outro lado, a experiência norte-americana - common law - denota uma prática jurisdicional na qual o juiz conjuga em suas decisões o Direito e a Política. Com efeito, a incorporação da concepção de supremacia do Poder Judiciário e do consequente ativismo judicial no contexto brasileiro, reitera-se, nascida a partir da influência dos dois países citados, é motivo de discussão entre juristas. Dentre esses expoentes destacam-se Luis Roberto Barroso e Lenio Streck. O primeiro não apenas defende como relativiza a prática ativista, uma vez que considera o Supremo Tribunal Federal detentor da chamada "função iluminista". Em sentido oposto, Streck, a partir da construção de uma teoria da decisão, associa o ativismo judicial à postura discrionária e solipsista dos Tribunais, destacando o prejuízo às instituições e a impossibilidade de manutenção de qualquer decisão dessa espécie, posição a qual nos filiamos, coforme restará demonstrado ao longo do texto.
} 
Esse contexto de redemocratização pós-guerra, no qual se alavancou o protagonismo do Poder Judiciário, influi, por óbvio, na jurisdição constitucional. É nesse momento que se criam os Tribunais Constitucionais com a função específica de limitação do poder público. Nessa esteira, destacaram-se as ideias formuladas por Hans Kelsen, cuja tese, embora defendida há muito, ganhou contornos de primazia justamente em razão das atrocidades experimentadas pelo mundo nas décadas de 30 e 40 do século 20.

Nesse sentido, o citado jurista defendia a necessidade de criação de um Tribunal Constitucional, por vislumbrar a impossibilidade de o Parlamento desempenhar a atividade de "auto subordinação" à Constituição (KELSEN, 2003). Daí o estabelecimento de um órgão jurisdicional constitucional independente e distinto dele, ou de qualquer outra autoridade do Estado (KELSEN, 2003).

Destarte, cientes de que o processo de controle das leis não poderia ficar restrito ao soberano - e nem ao Parlamento - mas, ao contrário, necessitava de um Tribunal Constitucional para possuir legitimidade, os juristas abraçaram o arquétipo kelseniano de guardião judicial da Carta Magna, o que se refletiu na maior parte dos países ocidentais a partir da construção de estruturas judiciárias constitucionais pautadas no modelo por ele defendido (PANSIERI, 2016). Assim, com espeque na sua teoria, Kelsen "lança as premissas teóricas fundamentais para a sistematização do controle de constitucionalidade e da respectiva jurisdição constitucional" (ABBOUD, 2019, p. 482).

O modelo pensado por Kelsen que, conforme destacado, encontrou reverberação em grande parte do mundo pós-guerra, além de colocar o Tribunal Constitucional como figura principal, priorizou o aspecto formal do controle de constitucionalidade. Dessa forma, equiparou-se a função jurisdicional à legislativa - a primeira relativa à criação de uma norma específica e a segunda referente a uma norma geral (ABBOUD, 2019) - preterindo o aspecto material da norma.

Funda-se, pois, a teoria do legislador negativo, segundo a qual cabia ao Tribunal Constitucional a estrita função de anular um ato legislativo geral com base no critério formal, a partir da utilização do binômio "constitucionalidade/inconstitucionalidade". É indiscutível que Kelsen, a partir das bases teóricas do controle de constitucionalidade abstrato, limita o poder do Legislativo, todavia ignora ou subjulga a substância da norma, reduzindo o controle material ao aspecto igualmente formal (ABBOUD, 2019). Sendo assim, inexistindo diferença entre vigência e validade da norma, a teoria de Kelsen serve para reforçar o caráter da Constituição de mecanismo de legitimação formal do poder (TASSINARI, 2012).

Assim, inobstante as contribuições do modelo kelsiano para a construção do controle de constitucionalidade, as transformações experimentadas pelo constitucionalismo do século 20 , notadamente no que se refere ao seu entrelace com a hermenêutica jurídica, não permitem que, na atualidade, se valha da sua proposta. Em outras palavras, a noção de legislador negativo mostra-se inaplicável no atual cenário da jurisdição constitucional. Isso porque alguns fenômenos "parecem ter influenciado na sofisticação das técnicas de decisão dos órgãos da jurisdição constitucional" (SGARBOSSA; IENSUE, 2016, p. 175).

O primeiro deles foi o surgimento de casos concretos mais complexos que demandavam para a resolução uma nova abordagem interpretativa por parte dos Tribunais Constitucionais, o que ratificou a insustentabilidade da mera visão do controle de constitucionalidade (SGARBOSSA; IENSUE, 2016). Além disso, o contexto foi influenciado pela incorporação de direitos por parte das Constituições, o que passou a exigir um novo modelo de controle de constitucionalidade, antes inexistente (SGARBOSSA; IENSUE, 2016).

No Brasil, esse quadro é perceptível com mais clareza a partir da Carta de 1988. A natureza programática do seu texto, aliada ao (necessário) surgimento de mecanismos intepretativos aplicáveis ao direito e, por consequencia, à jurisdição constitucional, fundou um novo modelo de controle de constitucionalidade, rompendo-se a barreira binomial referente ao exercício jurisdicional das Cortes Constitucionais. Assim, a mera declaração de constitucionalidade/inconstitucionalidade de uma norma deixou de ser suficiente à atividade jurisdicional, o que, somado à concepção do Judiciário como intérprete criador do direito, permitiu o surgimento de técnicas interpretativas diversas capazes de auxiliar os Tribunais em suas funções, com o fito de proteger a Carta Maior e tutelar os direitos dos cidadãos.

É nesse contexto que se destacam as sentenças interpretativas, ou seja, aquelas capazes de "restringir o âmbito normativo do dispositivo da lei ou ato normativo sujeito ao controle de constitucionalidade" (MEYER, 2017, p. 21), a partir da concessão de um novo sentido à norma que permita a sua conservação no ordenamento jurídico, conforme será explicitado a seguir. 


\section{AS SENTENÇAS INTERPRETATIVAS DENTRO DO CONTEXTO DA JURISDIÇÃO CONSTITUCIONAL CONTEMPORÂNEA}

Após o processo de redemocratização do Brasil, a Constituição foi posta no cerne do debate jurídico, tendo seu papel reforçado, ao mesmo tempo em que se atribuiu relevância ao Poder Judiciário (TASSINARI, 2013). Diante desse cenário, o texto constitucional passou a ocupar papel central no ordenamento pátrio e os juízes tornaram-se protagonistas no processo de interpretação.

A concretização desse modelo de valorização e vinculação das leis ao texto constitucional influi diretamente no surgimento de um novo padrão de decisão. Isso porque, a partir desse instante, o Poder Judiciário se viu obrigado a expandir o leque interpretativo, uma vez que o tradicional exercício decisório binário da jurisdição constitucional não se mostrou suficiente para abarcar o seu papel de garantidor da força normativa da Constituição. Com isso, métodos interpretativos diversos passaram a fazer parte da decisão no controle de constitucionalidade, justamente como reflexo do cenário inaugurado com a Carta de $1988 .{ }^{4}$

Nesse momento a interpretação ganhou destaque, sobretudo como ferramenta de construção de um provimento decisório adequado ao Estado Democrático de Direito. No mesmo sentido, as razões desencadeadoras desse panorama relacionam-se com os objetivos e compreensões típicos do modelo de Estado construído a partir da redemocratização do Brasil, conforme explica Lenio Streck (2018, p. 375), ao afirmar que:

(...) se no Estado Democrático o Direito assume uma função transformadora, torna-se evidente que a concretização das promessas da modernidade constantes em uma Constituição Compromissária e Dirigente demanda uma nova postura do Poder Judiciário (e em especial da Justiça Constitucional).

Desse modo, o Poder Judiciário, envolto no hodierno modelo da jurisdição constitucional, assumiu a função de intérprete da Constituição, preenchendo um locus anteriormente ocupado pelo Legislativo. Com isso, o conjunto de intérpretes legitimados foi ampliado, o que se concretizou, na prática, por meio da atuação cada vez mais frequente do Supremo Tribunal Federal (ABBOUD, 2019).

É nesse panorama que o Supremo Tribunal Federal passa a utilizar com maior frequência as sentenças interpretativas na prática do controle de constitucionalidade concentrado. Essas decisões são proferidas em sede de jurisdição constitucional e "versam sobre a possibilidade hermenêutica da lei e não sobre o texto da lei em si" (ABBOUD, 2019, p. 655). Dessa maneira, é conferido ou excluído um sentido da norma sem, entretanto, alterar o seu texto, valorizando, por conseguinte, a presunção da sua constitucionalidade.

Nessa senda, destacam-se, como técnicas de decisão as duas espécies de sentenças interpretativas, quais sejam, a interpretação conforme a Constituição e a declaração de nulidade sem redução do texto. ${ }^{5}$ Vale ressaltar, nesse contexto, que a nomenclatura "sentenças interpretativas" é utilizada para se referir à decisão de um "tribunal que não lide diretamente com o texto da própria lei, mas, em vez disso, com uma - apenas uma - das normas expressas no texto e, portanto, em uma das suas possíveis interpretações" (GUASTINI, 2009, p. 63).

\footnotetext{
${ }_{4}$ Nesse sentido, Riccardo Guastini (2009) explica em "La constitucionalización del ordenamiento jurídico: el caso italiano", que, em contraposição à insuficiência da técnica de interpretação literal na resolução dos casos concretos, foi necessária a utilização de mecanismos interpetativos capazes de encontrar um significado constitucional não derivado da literalidade do texto, a fim de concretizar a essência da Carta Maior. Na visão do autor, o surgimento e a valorização dessas técnicas constitui-se como uma das condições de constitucionalização do ordenamento jurídico.

Acerca da classificação dos métodos interpretativos, é interessante, mais uma vez, citar Guastini (2009) que em "La constitucionalización del ordenamiento jurídico: el caso italiano". Tendo como referência o exercício da jurisdição na Itália, o autor reafirma a importância da adequação das leis à Constituição a partir do exercício interpretativo que é praticado tanto pelos juízes da Corte Constitucional quanto os juízes de instâncias inferiores. Do mesmo modo, destacando a jurisprudência da Corte Constitucional do país, ele afirma que a interpretação adequada das normas infraconstitucionais pode ser realizada por meio de vários mecanismos, dentre os quais a interpretação, conforme a Constituição e a declaração de inconstitucionalidade sem redução de texto, que estariam englobadas na nomenclatura sentenças interpretativas. Nesse sentido, a primeira técnica serviria para rejeitar qualquer dúvida acerca da legitimidade constitucional da norma polissêmica, conservando a validez da Constituição a partir de uma interpretação conforme a Constituição. A segunda técnica, por outro viés, seria a de aceitação (de anulação), aplicada quando a Corte não anula a disposição legal, mas apenas o seu sentido inconstitucional, fazendo prevalecer somente aquele compatível com a Constituição.
} 
A interpretação, conforme a Constituição, técnica interpretativa consagradora de "um salto paradigmático, que rompe com as concepções tradicionais de interpretação constitucional e com a própria concepção de separação de poderes de Estado" (STRECK, 2018, p. 401), funciona como instrumento fundamental no processo de constitucionalização dos textos infraconstitucionais, e se concretiza quando a lei admite interpretação compatível com a Carta Magna (STRECK, 2018).

Destarte, nas hipóteses em que uma norma infraconstitucional comportar mais de um significado ou interpretação possível, sendo uma, ao menos, constitucional, o intérprete deve buscar a interpretação que consagre a sua constitucionalidade (TAVARES, 2018).

Salienta-se que a importância deste princípio interpretativo é deflagrada quando se verifica a existência de hipóteses em que a mera declaração de inconstitucionalidade de uma norma gera mais consequências maléficas do que benefícios (STRECK, 2018). Neste sentido, ao comparar o mandamento infraconstitucional com a Constituição Federal, o órgão julgador encontra, por meio da realização da interpretação conforme, uma solução mediana, capaz de equilibrar e concretizar o anseio do recorrente, sem, entretanto, criar um cenário geral mais desfavorável a partir da declaração de inconstitucionalidade da norma.

Neste ponto é válida, mais uma vez, a transcrição dos ensinamentos de Streck (2018, p. 377), que define o debatido mecanismo interpretativo de maneira a não deixar dúvidas ao afirmar que

a interpretação conforme a Constituição é mais do que um princípio, mas um modo de interpretar a legislação à luz do texto constitucional, até porque não há nada mais imanente a uma Constituição do que a obrigação de que todos os textos normativos do sistema sejam interpretados de acordo com ela.

Vê-se, portanto, que a aplicação dessa técnica interpretativa protege a norma e evita a sua expurgação do ordenamento jurídico, valorizando o princípio da presunção de constitucionalidade dos atos normativos, mediante a aplicação de uma hermenêutica "constitucionalizante".

Ao lado da espécie de interpretação conforme a Constituição existe um segundo instrumento interpretativo, denominado declaração de nulidade sem redução do texto, que, do mesmo modo, se encontra abrangido pelo gênero "sentenças interpretativas".

Como o próprio nome demonstra, a declaração de inconstitucionalidade sem redução do texto é utilizada quando o órgão julgador pretende expressamente fixar a inconstitucionalidade de uma norma infraconstitucional. Observa-se que, em sentido antagônico, na interpretação conforme a Constituição, não há declaração de inconstitucionalidade, mas, sim, de constitucionalidade de um significado da norma a partir da interpretação conferida pelo Poder Judiciário.

Diante do exposto, é possível perceber que, enquanto a interpretação conforme a Constituição busca adjudicar um significado à norma legal, a declaração de nulidade parcial sem redução do texto visa a excluir hipóteses específicas da aplicação da lei (SILVA, 2006). Assim, haverá decisão interpretativa aditiva apenas nos casos em que for utilizada a interpretação conforme a Constituição (RIBEIRO, 2011), ainda que em nenhum dos casos ocorra a modificação do texto, como ensina Streck (2018, p. 417):

(...) mesmo que a interpretação conforme a Constituição seja o inverso da nulidade parcial, em nenhum dos dois casos há amputação formal de texto. No primeiro caso, há uma adição de sentido, pelo qual se alça o texto original à compatibilização com a Constituição, evitando-se a expunção do sistema. No segundo caso, há uma redução de incidência, em que se declara inconstitucional um certo segmento ou seção "ideal" do texto normativo.

Em suma, na interpretação conforme a Constituição não se declara ("decide") uma nova situação concreta, mas apenas se cria/confere uma nova interpretação ao dispositivo infraconstitucional, tendo por substrato fundamental os ditames previstos na Carta Maior, enquanto na declaração de nulidade sem redução de texto é firmado entendimento excluindo-se do sistema a aplicação da parte inconstitucional do texto.

Frisa-se que a importância das sentenças interpretativas no exercício da função de interpretação das normas infraconstitucionais foi reforçada no ano de 1999 com a promulgação da Lei 9.868/1999, que institucionalizou estes dois mecanismos, permitindo a quebra do paradigma clássico referente à função meramente mecanicista do Poder Judiciário, admitindo-se a possibilidade de este agir não mais apenas como "legislador negativo" no exame da legalidade de uma norma infraconstitucional (STRECK, 2018). 


\section{OS LIMITES HERMENÊUTICOS E O DESVIRTUAMENTO DAS SENTENÇAS INTERPRETATIVAS}

Como destacado, as sentenças interpretativas adquiriram primordial importância no contexto contemporâneo da prática jurisdicional, sendo utilizadas como instrumentos de realização do enquadramento constitucional dos textos e de manutenção da harmonia do ordenamento jurídico que sustenta o Estado Democrático Constitucional de Direito. Ocorre que, em muitos momentos, os Tribunais pátrios aplicam-nas de maneira equivocada, seja porque o mecanismo escolhido para determinado caso não é formalmente apropriado, seja porque em alguns julgamentos os argumentos justificadores das técnicas interpretativas em questão são utilizados de forma indiscriminada e sem muitas explicações (SILVA, 2006).

Por vezes, a Corte Suprema ancora-se na interpretação conforme como princípio absoluto, buscando fornecer um direcionamento constitucional à norma, mesmo nos casos flagrantemente inconstitucionais (MEYER, 2017), quando o correto seria buscar outro método interpretativo, qual seja, a declaração de nulidade sem redução do texto ${ }^{6}$. O contrário também se verifica, o que apenas corrobora a confusão entre os institutos como tendência da Suprema Corte (MEYER, 2017). E não é só: há momentos em que o órgão utiliza-se das técnicas como alternativa, a fim de evitar o confronto direto com o Poder Legislativo. Tal atitude apenas reforça o caráter descricionário da decisão, colaborando para o desvirtuamento dos mecanismos interpretativos em destaque (MEYER, 2017).

Em síntese, a normatização das sentenças interpretativas bem como a utilização maciça por parte dos Tribunais, em especial pelo Supremo Tribunal Federal, embora tenha reforçado a prática da interpretação, fazendo surgir, em muitos julgamentos, soluções alternativas à simples declaração de constitucionalidade ou inconstitucionalidade, vulgarizou até certo ponto esse método, o que explica a sua aplicação errônea em diversos julgamentos.

Assim, afora as impropriedades e atecnias suscitadas anteriormente, percebe-se que em muitos casos aplicam-se as sentenças interpretativas em afronta aos limites hermenêuticos possíveis, o que reforça a subjetividade da decisão e fomenta o ativismo judicial. Daí o Poder Judiciário assume a posição de legislador positivo, portando-se como se estivesse acima da própria Carta Magna, o que não pode ser concebido.

Por isso, mostra-se imperioso discutir as balizas a serem observadas no momento da aplicação da interpretação conforme e da declaração de nulidade sem redução do texto. Isso porque ambos os mecanismos interpretativos em questão devem ser necessariamente analisados sob a égide da hermenêutica, o que implica análise das condições de possibilidades que emergem do procedimento interpretativo e suas repercussões no mundo jurídico (STRECK, 2018).

Aqui se mostra necessário salientar que, embora a declaração de nulidade sem redução do texto e a intepretação conforme a Constituição incidam sobre o sentido da norma, as consequências produzidas pelas técnicas são diversas (STRECK, 2018). No primeiro caso, um sentido do texto é expungido do ordenamento, enquanto na interpretação conforme salva-se o texto normativo por meio de uma adaptação à Constituição (STRECK, 2018), o que torna ainda mais salutar o estabelecimento de balizas quando do instrumento aditivo de sentido. Destarte, até mesmo pelo caráter inclusivo da interpretação conforme, ela precisa ser limitada com o fito de encontrar legitimidade no cenário do Estado Democrático de Direito. Nesse sentido, mostra-se necessário entender que essa técnica implica decisão ativa do julgador no controle de constitucionalidade, o que não significa, entretanto, que ela possa estar sujeita a um requisito mínimo de razoabilidade. Em outras palavras, faz-se mister que o mecanismo em questão detenha-se ao preceito legal, interpretado conforme a Constituição, nos casos em que "seja incontestável que o legislador ordinário acolheu critérios e soluções opostos aos critérios e soluções do legislador constituinte" (STRECK, 2018, p. 302).

É interessante destacar que as balizas a serem respeitadas pelo intérprete no momento do exercício da jurisdição constitucional são motivo de discussão tanto na doutrina quanto na jurisprudência.

BRASIL, STF, ADI 4815, Rel. Min. Carmen Lúcia, j. 10/6/2015, DJ 1º/2/2016. 
Destarte, enquanto Medeiros afirma que a intepretação 7 não pode contrariar a intenção do legislador ou o sentido inequívoco da lei (MEDEIROS apud MEYER, 2017), podendo, portanto, ser utilizada somente nas hipóteses em que não seja possível identificar o desejo inicial daquele que criou a norma, ou naqueles casos em ela não interfira nessa vontade, Streck (2018) assevera que esse tipo de abordagem não pode mais prevalecer no paradigma contemporâneo da hermenêutica jurídica. Isso porque não é possível, no hodierno cenário, cotejar a intenção do legislador ou o objetivo da norma traduzida em texto (STRECK, 2018). Com efeito, "no plano da crítica hermenêutica do direito, fica extremamente dificultado o apelo tanto à intenção do legislador como à vontade objetivada na norma" (STRECK, 2018, p. 383).

Debate à parte, parece-nos inconteste que um limite muito claro às sentenças interpretativas ergue-se em consonância com as hipóteses nas quais é possível a aplicação dessas técnicas. Nessa esteira, é evidente, em primeiro lugar, que a principal baliza é a própria Constituição. Ora, se a pretensão é conferir/excluir sentido a uma norma tendo por fundamento um escólio extraído da Carta Magna, é inegável que é o texto maior o primaz referencial nesse processo. Dessa forma, sendo certo que as sentenças interpretativas atingem a possibilidade hermenêutica da norma, permitindo à Corte adequar a lei infraconstitucional aos ditames constitucionais, a sua aplicação limita-se às situações em que a lei não possuir o mesmo sentido da norma constitucional. Dizendo de outra maneira: não se pode utilizar essa técnica de interpretação quando o texto infraconstitucional repetir o sentido da Carta Magna, ou nas hipóteses em que ele possuir apenas um sentido que seja contrário à Constituição, pois, nesses casos, basta declarar, respectivamente, a sua constitucionalidade ou a sua inconstitucionalidade.

Na mesma esteira, não se pode conceber que a sentenças interpretativas violem as competências estabelecidas na Constituição, sob pena de configuração de uma decisão discricionária, ativista e incongruente com o contexto democrático.

Essa questão ficará ainda mais clara quando for apresentado o exemplo prático relativo ao julgamento da ADI 6.012, no tópico 6 do presente artigo. Certo é que, diante de tantos detalhes, é importante o estudo aprofundado acerca das hipóteses de cabimento e dos consequentes limites das sentenças interpretativas, a fim de reforçar a sua importância, evitar a banalização do seu sentido e combater o ativismo judicial que nasce nas hipóteses em que há aplicação desses mecanismos em desrespeito aos contornos constitucionais, necessários a qualquer decisão.

\section{JUDICIALIZAÇÃO, ATIVISMO JUDICIAL, DISCRICIONARIEDADE E INTERPRETAÇÃO CONSTITUCIONAL}

A análise sobre o protagonismo judicial e a intepretação constitucional dialoga com o tema do ativismo judicial, especialmente na atual conjuntura brasileira, na qual, como já assinalado, existe forte processo de judicialização de algumas matérias, aliado à valorização da Suprema Corte como instituição.

O primeiro aspecto a se compreender, nesse diapasão, é a diferença entre o ativismo judicial e a judicialização da política, notadamente no Brasil, onde há muita confusão sobre o assunto. Assim, embora não seja esse o cerne primaz do presente artigo, mostra-se cabível uma breve explanação, a fim de diferenciar os dois institutos. $\mathrm{O}$ ativismo judicial vincula-se ao exercício discricionário e ilimitado das funções do Poder Judiciário; a judicialização é caracterizada pela busca dos cidadãos pelo Poder Judiciário, ante a omissão estatal na tutela dos direitos fundamentais. Nesse sentido, pode-se afirmar, com espeque na lição de Streck, Tassinari e Lepper (2015), que a judicialização se mostra como uma questão social, que independe da vontade do órgão judicante, porque deriva de fatores que, em sua origem, não dizem respeito à jurisdição, uma vez que se relacionam, inicialmente, com o contexto de ampliação de direitos, passam pela incapacidade de efetivação por parte do Estado e desaguam no aumento da litigiosidade.

Vê-se, pois, que, diferente da judicialização da política, o ativismo, nascido no núcleo do Poder Judiciário, refere-se à conduta dos tribunais e de juízes no desempenho das suas funções. Em outros termos, o ativismo judicial insere-se e se relaciona aos critérios utilizados nas decisões judiciais.

\footnotetext{
É de se destacar que, embora Medeiros se refira especificamente à interpretação conforme a análise, em nosso entender pode ser expandida também para a declaração de nulidade sem redução do texto.
} 
É nesse contexto que Streck (2017) relaciona o ativismo com a discricionariedade, ressaltando que o ativismo judicial para "defesa" dos direitos fundamentais apenas reproduz, na contemporaneidade, os mesmos conceitos que engendram o conceito de discricionariedade. Tal fato mostra-se preocupante porque a forma com que se pratica a discricionariedade no Brasil se aproxima, no campo da linguagem, da arbitrariedade (STRECK, 2017).

Nesse ponto reside a relação do ativismo judicial com a interpretação conforme e a nulidade sem redução do texto: sendo elas técnicas comumente utilizadas para o exercício dessa postura proativa da Corte Suprema, tornam-se um instrumento de reforço da discricionariedade e do arbítrio quando não conhece/ respeita os limites formais e semânticos da Constituição. Isso porque a aplicação das sentenças interpretativas em hipóteses incabíveis traz consigo um grau de subjetividade do intérprete que pode representar um atentado à separação de poderes e à legitimidade do Estado Democrático. Diante disso, esses mecanismos devem ser utilizados nos limites da legalidade e da razoabilidade (STRECK, 2018).

Veja-se que nesse contexto dois caminhos podem ser trilhados pelo intérprete julgador, ocasionando, entretanto, o mesmo resultado: a configuração do ativismo judicial. Assim, de um lado, é possível, por meio da aplicação errônea das sentenças interpretativas (seja pela atecnia, seja pela impropriedade da sua utilização no caso concreto), materializar uma decisão ativista. Por outro viés, também se percebe a possibilidade de utilização desses mecanismos interpretativos (ou de sua nomenclatura) como verdadeiros subterfúgios conceituais de reforço às decisões solipsistas, atribuindo-Ihes um caráter prático e justificador dessas decisões, que ignora os limites constitucionais típicos do Estado Democrático de Direito.

Parece indubitável, destarte, a importância dessa abertura interpretativa na construção de provimentos pelos tribunais. Ocorre que a utilização desarrazoada dessa ferramenta permite o aparecimento do indesejado ativismo judicial, que se pauta em posturas discricionárias e arbitrárias do Poder Judiciário (TASSINARI, 2016).

Em outros termos, o processo analítico, que resulta nas sentenças interpretativas, deve respeitar as balizas contidas no próprio texto, bem como os limites hermenêuticos e normativos previstos na Constituição Federal. Do mesmo modo, não se pode, sob o pretexto de se "fundamentar" uma decisão discricionária, aplicar a técnica da interpetação conforme ou da declaração de nulidade sem redução do texto e sem obedecer aos critérios informadores da propria decisão.

Por esse motivo, reforça-se a necessidade de fundamentação das decisões e de respeito à Constituição no momento da realização da interpretação e da utilização das técnicas ora discutidas, o que perpassa, como já destacado, pela aplicação desses mecanismos somente nas hipóteses em que eles se mostrarem pertinentes. Caso contrário, passa-se ao terreno movediço do ativismo judicial e de sua arbitrariedade, subjetivismo e discricionariedade.

\section{A ADI 6.012/MS:}

\section{A Linha Tênue Entre as Sentenças Interpretativas e o Ativismo Judicial}

Até o presente momento buscou-se construir e ratificar o entendimento de que quando se utiliza a intepretação conforme a Constituição e a declaração de nulidade sem redução do texto fora dos limites e hipótese cabíveis, abre-se espaço para o aparecimento do ativismo judicial e da discricionariedade que vem a reboque de forma implícita. Pois bem, partindo dessa premissa, visa-se agora a apresentar um exemplo concreto, recentemente julgado pelo STF, no qual se verificou, notadamente no voto do relator (ora analisado), o desrespeito às balizas hermenêuticas e ao texto constitucional.

O citado caso refere-se ao julgamento da ADI no 6.012/MS, proposta pela Confederação Brasileira de Trabalhadores Policiais Civis (Cobrapol), ante o artigo 167, IV e $\S 1$, do Decreto 12.118/2006, editado pelo governador de Mato Grosso do Sul. Em apertada síntese, os dispositivos legais questionados fixavam a indenização pelo exercício do magistério policial, entretanto estabeleciam limites indenizatórios máximos distintos com base no cargo da Carreira de Policial Civil ocupado pelo servidor, o que gerava, na prática, hipóteses de diferenciação dos valores pagos aos Delegados de Polícia e aos servidores das demais carreiras policiais, ainda que o número de aulas ministradas fosse o mesmo. Perante esse fato, a autora da ação questionou a validade dos dispositivos legais citados, utilizando como fundamento a suposta violação do artigo 5o, caput e inciso I, da Constituição Federal (princípio da isonomia). 
Conforme será demonstrado, de início já cabe crítica ao voto do relator, ministro Alexandre de Moraes, pela atecnia formal no momento da decisão, tendo em vista que foi conferida ao dispositivo impugnado "interpretação conforme a Constituição sem redução de texto", o que demonstra - como já fora explicitado - a confusão que ainda persiste no seio do Supremo Tribunal Federal acerca dos conceitos e das hipóteses de cabimento de cada um dos citados mecanismo interpretativos.

Ultrapassada essa primeira observação relativa à discussão sobre qual seria o correto instrumento interpretativo (interpretação conforme a Constituição ou declaração de nulidade sem redução do texto), ${ }^{8}$ ou se o caso em tela permitia a aplicação das técnicas em questão, foquemos na hermenêutica do julgamento.

Pois bem. O ministro relator iniciou o seu voto reiterando a importância dada pela Constituição ao "constante aprimoramento profissional no âmbito da Administração Pública", o que tornava inegável o interesse em contar com instrutores, e justifica o desempenho de atividades de docência dos servidores públicos da força policial. Em seguida, prosseguiu o ministro ressaltando que, embora o artigo 39 da Carta Magna autorize o poder público a fixar subsídios diferentes para cada uma das carreiras, em observância às específicas atribuições e complexidades de cada cargo, ele não pode ser utilizado como argumento por parte do Estado, uma vez que o caso concreto versa acerca de pecúnia indenizatória e não sobre subsídios.

É de se observar, ab initio que, na prática, embora sejam institutos diferentes, tanto a indenização quanto o subsídio relacionam-se à remuneração do servidor e o seu recebimento gera o mesmo resultado: a contraprestação financeira pelo serviço prestado. Esse, todavia, não é o cerne principal da decisão, embora a interpretação específica desse artigo seja, em si, fundamento para a postura ativista do ministro.

Isso porque, em verdade, o ponto crítico da decisão é a não observância por parte do julgador do disposto no artigo $37, \mathrm{X}$, da Constituição Federal, que consagra a impossibilidade de fixação ou alteração de subsídios de servidor público pelo Poder Judiciário, estabelecendo essa competência exclusiva para o Poder Legislativo a partir do seguinte texto: "A remuneração dos servidores públicos e o subsídio de que trata o $\S$ 4o do art. 39 somente poderão ser fixados ou alterados por lei específica, observada a iniciativa privativa em cada caso, assegurada revisão geral anual, sempre na mesma data e sem distinção de índices".

Nota-se que tal dispositivo possui tanta relevância no ordenamento jurídico que foi fixado pelo próprio Supremo Tribunal Federal a partir da edição da Súmula Vinculante no 37, que afirma que "não cabe ao Poder Judiciário, que não tem função legislativa, aumentar vencimentos de servidores públicos sob o fundamento de isonomia".

Ocorre que, a partir do momento em que o ministro relator reitera a cautelar anteriormente concedida em decisão monocrática e confere interpretação conforme a Constituição, sem redução de texto, ao $\S 10$ do artigo 167 do Decreto 12.118/2006 para que o percentual ali previsto passe a incidir sobre a mesma base de cálculo referida no inciso IV (subsídio da classe inicial de Delegado de Polícia), independentemente do cargo ocupado pelo servidor que exerce atividades de ensino na Academia de Polícia, ele altera a remuneração dos servidores públicos, violando verticalmente a regra consagrada na Carta Magna.

Observa-se que o ministro relator sequer cita em seu voto o artigo $37, \mathrm{X}$, da Constituição Federal, tendo feito, somente, referência à Súmula Vinculante no 37, para, em seguida, negar a sua aplicação no caso concreto com base no frágil argumento de que de tal atitude não configuraria aumento de vencimentos, mas apenas o estabelecimento de um teto indenizatório pelo exercício do magistério policial, a partir da utilização de uma técnica interpretativa.

Nesse contexto, não restam dúvidas acerca da atitude ativista do ministro Alexandre de Moraes no julgamento da ação em tela. Ora, claro está o fato de que, a partir da aplicação (equivocada, frise-se) de um mecanismo interpretativo, o ministro desrespeitou um limite expresso no texto da Carta Maior. De forma ainda mais aprofundada e, novamente, utilizando-se da lição de Abboud (2019, p. 1.339), que classifica as espécies de ativismo judicial, configura-se o denominado ativismo contra os limites do texto, a partir da aplicação de uma interpretação que foge à literalidade e viola o ponto nevrálgico do texto constitucional.

\footnotetext{
No caso em tela, em nosso entendimento, não havia espaço para a aplicação de uma técnica interpretativa, mas, sim, para a declaração de inconstitucionalidade do dispositivo legal impugnado, como fora explicitado pelo ministro Gilmar Mendes em seu voto, notadamente por não haver adição e nem exclusão de sentido da norma, mas somente a verificação que, por estar eivada de vício formal de competência, não merecia permanecer no ordenamento jurídico.
} 
Há ainda outro aspecto que corrobora o ativismo decisório do ministro relator - e de mais nove integrantes do STF que seguiram o seu posicionamento -, qual seja, o fato de que, para além da regra Constitucional e do entendimento sumulado pelo próprio Tribunal, existem também decisões proferidas pela Corte que consagram a impossibilidade de modificação de remuneração do servidor público por poder que não seja o Legislativo, ${ }^{9}{ }^{10}$ o que demonstra a ausência de integridade e coerência nas tomadas de decisão, outro fator caracterizador do ativismo judicial.

Vê-se, de maneira cristalina, que no exemplo discutido o julgador utilizou-se da sentença interpretativa (inobstante a falta de técnica no momento da aplicação) para firmar a postura ativista, tão danosa ao sistema democrático.

Em contrapartida, destaca-se o caminho diverso que foi seguido, única e - a nosso ver - corretamente, pelo ministro Gilmar Mendes no julgamento da ADI ora debatida. Em primeiro lugar, o citado julgador estabeleceu, com espeque nos artigos 37, X e 169 § 1ำ da Constituição Federal, a obrigatoriedade de lei para fixação da remuneração de servidor público, reforçando a tese de que apenas o Poder Legislativo é competente para estabelecer tal determinação, conforme se extrai do trecho a seguir assinalado.

Assim, a disciplina jurídica da remuneração funcional deve observância ao postulado constitucional da reserva absoluta de lei formal, sendo vedada a concessão de qualquer benefício remuneratório por ato estatal de menor positividade jurídica, estranha à atuação institucional do Poder Legislativo, na apreciação de norma proposta pela autoridade competente.

Destarte, partindo dessa premissa que limita o exercício dos Poderes Executivo e Judiciário, não restou alternativa ao ministro Gilmar Mendes senão declarar a inconstitucionalidade da lei, uma vez que a parcela remuneratória foi fixada pelo Poder Executivo de Estado do Mato Grosso do Sul, por meio de Decreto, o que fere a reserva legal de iniciativa do Poder Legislativo. Ademais, ressalta-se que o voto em questão não seguiu o entendimento do relator e dos demais pares, porque também não é competência do Poder Judiciário estabelecer ou alterar a remuneração do servidor público, inclusive utilizando-se, para isso, de técnica interpretativa. Do mesmo modo, caso o voto dissidente ratificasse a interpretação utilizada pela maioria da Corte, incorreria, da mesma forma, em ativismo judicial. Diante disso, há de se louvar, nesse caso específico, o voto minoritário proferido, uma vez que obedeceu aos limites do texto constitucional, notadamente no que se refere à observância das barreiras previstas para o exercício do Poder Judiciário.

Ante o quadro exposto, verifica-se como é possível o Poder Judiciário utilizar equivocadamente a interpretação conforme a Constituição e a declaração de nulidade sem redução de texto como fundamento instrumental da postura ativista, assumindo, em muitos casos, a função de legislador, ultrapassando os limites impostos pela Constituição a partir da subjetividade e da discricionariedade típicas do ativismo judicial e deslegitimando o Estado Democrático de Direito, no momento em que reforça a interferência inapropriada de um poder sobre os demais.

É importante ressaltar que a utilização das sentenças interpretativas no controle de constitucionalidade é legítima, até mesmo como instrumentos de concessão de um sentido hermenêutico constitucional ao dispositivo legal que seja condizente com o texto maior. A questão que se arvora, entretanto, diz respeito à análise do sentido da norma e, por conseguinte, da aplicação dessas técnicas interpretativas. É nesse momento que se verifica como é tênue a linha que separa a utilização dos mecanismos interpretativos da exacerbação de sentido da decisão e do consequente ativismo judicial.

Diante de todo exposto, percebe-se que não se pode ignorar nem a Carta Magna e tampouco os limites hermenêuticos no momento de se analisar uma norma infraconstitucional e, especialmente, de se utilizar dos recursos interpretativos previstos em Lei.

STF. ADI 3.369-MC, Rel. Min. Carlos Velloso, Dje 18.2.2005.

${ }^{10}$ ADI 2075-MC, Rel. Min. Celso de Mello, Dj 27.6.2003. 


\section{CONCLUSÃO}

O presente texto destacou que o protagonismo do Poder Judiciário dentro do ordenamento jurídico, aliado ao desenvolvimento dos conceitos do direito e da hermenêutica, ampliou a perspectiva decisória na jurisdição constitucional a partir da consagração de métodos interpretativos. Destarte, desde a valorização de novas alternativas interpretativas ganhou destaque a natureza criativa do Poder Judiciário, em favor das tutelas buscadas pela sociedade. Daí foram difundidas no Brasil as sentenças interpretativas, consagradas como importante mecanismo de auxílio no contexto de transformação da jurisdição constitucional.

Essa confluência de fatores fortaleceu o ativismo judicial que ocorre sempre que o Judiciário atua como legislador positivo, ignorando as balizas presentes no texto constitucional e as possibilidades hermenêuticas do caso concreto. Perante isso, multiplicam-se, no Supremo Tribunal Federal, órgão protetor da Constituição, decisões desarrazoadas e discricionárias, seja pela utilização das sentenças interpretativas em hipóteses incabíveis, seja pela afronta ao texto da Carta Magna, ou, ainda, pela aplicação das técnicas citadas como fundamento prático das decisões subjetivas.

É exatamente essa questão fundamental que o artigo buscou tratar: a tênue linha que separa o exercício regular das funções do STF a partir da utilização da das sentenças interpretativas e da prática do ativismo judicial. Nesse sentido, demonstrou-se que não há natureza "boa" ou "ruim" no ativismo, mas, sim, um exercício do poder constitucionalmente outorgado de maneira disforme e subjetiva.

Assim sendo, ficou clara a necessidade de se reforçar esse complexo debate relativo à jurisdição constitucional, hermenêutica jurídica, função jurisdicional e Constituição. Isso porque, ainda que o mecanismo interpretativo sirva para harmonizar a vontade do legislador às mudanças fáticas ocorridas no seio da sociedade, deve ser aplicado respeitando, em instância última, o texto da Constituição, bem como os limites hermenêuticos implícitos no próprio processo interpretativo.

Em suma, considerando que o banimento ou estabelecimento de qualquer sentido normativo do texto, por parte dos tribunais, quase sempre ocasiona a mudança, ainda que mínima, do sentido original estabelecido pelo legislador, ${ }^{11}$ é - mais do que prudente - necessário obedecer às balizas hermenêuticas e constitucionais no momento da realização da intepretação de normas infraconstitucionais. É esse o caminho para a consolidação do equilíbrio e da autonomia entre os poderes, assim como da força normativa da Constituição, características típicas do Estado Democrático de Direito.

\section{REFERÊNCIAS}

ABBOUD. Georges. Processo constitucional brasileiro. São Paulo: Thomson Reuters, 2019.

BRASIL. Constituição da República Federativa do Brasil. Brasília, DF, 1988.

BRASIL. Supremo Tribunal Federal. Ação Direta de Inconstitucionalidade 4815. Relatora: ministra Carmen Lúcia. DJ 1/2/2016. Disponível em: http://portal.stf.jus.br/processos/detalhe.asp?incidente=4271057. Acesso em: 15 jun. 2020.

BRASIL. Supremo Tribunal Federal. Ação Direta de Inconstitucionalidade: ADI no 6012/MS. Relator: ministro Alexandre de Moraes. DJ: 15/10/2019. Disponível em: http://portal.stf.jus.br/processos/detalhe.asp?incidente=5540967. Acesso em: 11 jun. 2020.

BARROSO, Luís Roberto. Contramajoritário, representativo e iluminista: os papéis das cortes constitucionais nas democracias contemporâneas. Rev. Direito e Práxis, Rio de Janeiro, v. 9, n. 4, p. 2.171-2.228, 2018. Disponível em: http://www.e-publicacoes.uerj.br/index.php/revistaceaju/article/view/30806/21752. Acesso em: 11 jun. 2020.

GUASTINI, Riccardo. La constitucionalización del ordenamiento jurídico: el caso italiano. In: CARBONELL, Miguel (ed.). Neoconstitucionalismo(s). 4. ed. México: Trotta, 2009. p. 49-73.

KELSEN, Hans. A garantia jurisdicional da Constituição (a justiça constitucional). Tradução Jean François Cleaver. Revista Direito Público, v. 1, n. 1, p. 90-130, 2003.

MEDEIROS. A decisão de inconstitucionalidade: os autores, os conteúdos e os efeitos da decisão de inconstitucionalidade da lei. Lisboa: Universidade Católica, 1999.

\footnotetext{
${ }^{11}$ Nesse sentido é o voto proferido pelo ministro Gilmar Mendes no julgamento da ADPF no 132, que se encontra disponível em: http://redir. stf.jus.br/paginadorpub/paginador.jsp?docTP=AC\&docID=628633
} 
MEYER, Emilio Peluso Neder. Decisão e jurisdição constitucional: crítica às sentenças intermediárias, técnicas e efeitos do controle de constitucionalidade em perspectiva comparada. Rio de Janeiro: Lumen Juris, 2017.

PANSIERI, Flávio. Carl Schmitt e o debate sobre o guardião da Constituição. In: SCHELEDER, Adriana Fasolo Pilati; ROBL FILHO, Ilton Norberto (org.). Jurisdição Constitucional e Democracia. Itajaí: Editora da Univali, 2016. p. 41-59.

RIBEIRO. Júlio de Melo. Controle de constitucionalidade das leis e decisões interpretativas. Revista de Informação Legislativa, Brasília, n. 191, jul./set. 2011.

SAMPAIO, José Adércio Leite. A Constituição reinventada pela jurisdição constitucional. Belo Horizonte: Del Rey, 2002.

SGARBOSSA, Luis Fernando; IENSUE, Geziela. Os poderes paralegislativos e paraconstitucionais da jurisdição constitucional: técnicas de decisão dos órgãos da jurisdição constitucional na contemporaneidade e a produção normativa estatal. In: SCHELEDER, Adriana Fasolo Pilati; ROBL FILHO, Ilton Norberto (org.). Jurisdição constitucional e democracia. 1. ed. Itajaí: Editora da Univali, 2016. p. 165-190.

SILVA, Diogo Bacha e. Os contornos do ativismo judicial no Brasil: o fetiche do Judiciário brasileiro pelo controle dos demais poderes. Revista de Informação Legislativa, v. 199, p. 163-178, 2013.

SILVA, Virgílio Afonso da. Interpretação conforme a constituição: entre a trivialidade e a centralização judicial. Revista Direito GV, v. 2, n. 1, p. 191-210, jan. 2006. ISSN 2317-6172.

STRECK, Lenio Luiz. Dicionário de hermenêutica jurídica: quarenta temas fundamentais da teoria do direito à luz da crítica hermenêutica do direito. Belo Horizonte: Letramento; Casa do Direito, 2017.

STRECK, Lenio Luiz. Jurisdição constitucional. Rio de Janeiro: Forense, 2018.

STRECK, Lenio Luiz; TASSINARI, Clarissa; LEPPER, Adriano Obach. O problema do ativismo judicial: uma análise do caso MS3326. Revista Brasileira de Políticas Públicas, Brasília, v. 5, Número Especial, p. 51-61, 2015.

TASSINARI, Clarissa. Ativismo judicial: uma análise da atuação do judiciário nas experiências brasileira e norte-americana. 2012. Dissertação (Mestrado em Direito) - Universidade do Vale do Rio Sinos, 2012. Disponível em http://biblioteca.asav. org.br/vinculos/tede/ClarissaTassinari.pdf. Acesso em: 21 jun. 2020.

TASSINARI, Clarissa. A supremacia judicial consentida: uma leitura da atuação do Supremo Tribunal Federal a partir da relação direito-política. 2016. Tese (Doutorado em Direito) - Universidade do Vale do Rio Sinos, 2016. Disponível em: http://www. repositorio.jesuita.org.br/handle/UNISINOS/6403. Acesso em: 19 dez. 2019.

TASSINARI, Clarissa. A atuação do Judiciário em tempos de Constitucionalismo Contemporâneo: uma crítica ao ativismo judicial. Revista da Faculdade de Direito do Sul de Minas, v. 28, p. 31-46, 2013.

TAVARES, André Ramos. Curso de Direito Constitucional. 16. ed. São Paulo: Saraiva, 2018. 